\title{
On two poorly known Eurasian dictynid species (Aranei: Dictynidae), with a description of a new genus
}

\author{
О Авух малоизвестных евроазиатских видах Аиктинид \\ (Aranei: Dictynidae), с описанием нового рода
}

\author{
Sergei L. Esyunin ${ }^{1}$, Alireza Zamani ${ }^{2}$, Tatyana K. Tuneva ${ }^{3}$

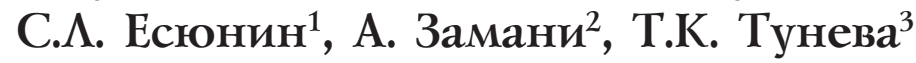

\footnotetext{
${ }^{1}$ Perm State University, Bukireva Street 15, Perm, Russia, 614600. E-mail: Sergei.Esyunin@psu.ru

${ }^{1}$ Пермский государственный университет, ул. Букирева 15, Пермь 614600 Россия.

${ }^{2}$ School of Biology, College of Sciences, University of Tehran, Tehran, Iran. E-mail: zamani.alireza5@gmail.com

${ }^{3}$ Institute of Plants and Animals Ecology Ural branch RAS, 8 March Str., 202, Ekaterinburg, Russia, 620144. E-mail: tuneva@ipae.uran.ru

${ }^{3}$ Институт экологии растений и животных УрО РАН, ул. 8 Марта, 202, Екатеринбург 620144 Россия.
}

KEY WORDS: spiders, Central Asia, new genus, redescription, new combinations, Kharitonovia gen.n.

КЛЮЧЕВЫЕ СЛОВА: пауки, Центральная Азия, новый род, переописание, новые комбинации, Kharitonovia gen.n.

ABSTRACT. A new genus and two poorly known species of the Dictynidae from Central Asia are (re)described. Dictyna uzbekistanica Charitonov, 1946, hitherto known from the holotype female from Uzbekistan, is redescribed and illustrated on the basis of the holotype and new material from Iran; it is transferred to a newly erected monotypic genus Kharitonovia gen.n. The widespread Central Asian "Nigma" laeta (Spassky, 1952) known from Tajikistan, western Azerbaijan and Iran is redescribed and illustrated on the basis of newly collected material from Iran. Dictyna uzbekistanica vittata Charitonov, 1946 syn.n. is synonymized with $K$. uzbekistanica (Charitonov, 1946). Four species of the genus Nigma Lehtinen, 1967 are shown to be treated as insertae sedis: "Nigma" conducens (O. Pickard-Cambridge, 1876) (Egypt), "Nigma" laeta (Spassky, 1952) (Central Asia), "Nigma" linsdalei (Chamberlin et Gertsch, 1958) (California), and "Nigma" longipes (Berland, 1914) (Kenya).

РЕЗЮМЕ. Новый род и два малоизвестных вида (пере)описаны из Центральной Азии. Dictyna uzbekistanica Charitonov, 1946, известная ранее только по голотипу-самке из Узбекистана, переописана и проиллюстрирована по голотипу и новым материалам из Ирана. Она перемещена в новь установленный монотипический род Kharitonovia gen.n. Широко распространенная центральноазиатская "Nigma" laeta (Spassky, 1952), известная из Таджикистана, Азербайджана и Ирана переописана и проиллюстрирована по новым материалам из Ирана. Dictyna uzbekistanica vittata Charitonov, 1946 syn.n. сведена в синонимы к K. uzbekistanica (Charitonov, 1946). Четыре вида рода Nigma Lehtinen, 1967: "Nigma" conducens (O. Pickard-Cambridge, 1876) (Египет), “Nigma” laeta (Spassky, 1952) (Централь- ная Азия), "Nigma" linsdalei (Chamberlin et Gertsch, 1958) (Калифорния) и "Nigma" longipes (Berland, 1914) (Кения), рассматриваются как insertae sedis.

\section{Introduction}

Dictynidae is a large spider family with worldwide distribution [Jocque, Dippenaar-Schoeman, 2006] that includes 578 extant species in 52 genera [WSC, 2016]. In the Palaearctic Region, the family is studied insufficiently. Only 183 species and 27 genera of Dictynidae have been known from this territory; our calculation is based on WSC [2016] and the latest additions by Esyunin, Sozontov [2016] and Zamani et al. [2016]. A third of all the Palaearctic species are known from one sex (48 from $q, 13$ from $\sigma^{7}$ ). Out of the 27 Palaearctic genera, six are monotypic. Finally, 17 species were described some 100 years ago and still remain known from the original descriptions only; of them, 12 were not illustrated. For example, four out of the 35 Palaearctic species of the genus Dictyna Sundevall, 1833 have never been redescribed and/or illustrated: $D$. armata Thorell, 1875 ( $0^{7}$; Ukraine), D. cronebergi Simon, 1889 (+; Turkmenistan), D. ignobilis Kulczyñski, 1895 (\$; Moldavia, Armenia), D. laeviceps Simon, 1911 ( $\sigma^{7}$; Algeria). Another example is the genus Lathys Simon, 1884, in which four out of the 35 Palaearctic species have never been redescribed and/or illustrated: L. cambridgei (Simon, 1874) (†; Israel), L. lepida O. Pickard-Cambridge, 1909 (†; Spain, Great Britain), L. lutulenta Simon, 1914 ( ; France).

While studying recently collected spider material from Iran, we have recognized two poorly known dictynid species. One of them is Dictyna uzbekistanica Charitonov, 1946, which was described from Uzbekistan and later redescribed by Charitonov [1946, 1969] 
on the basis of a single female. Since then, this species has not been rediscovered until the present study. An examination of both sexes of D. uzbekistanica has led us to the conclusion that actually this species is not conspecific with the generotype of Dictyna and belongs to a new genus, which is described herein.

The second species - Nigma laeta (Spassky, 1952) - was described on the basis of two females in the genus Dictyna from Tajikistan [Spassky, 1952]. Later, both sexes of this species were collected from around the type locality and poorly redescribed by Andreeva, Tyschchenko [1969]. Later, N. laeta was discovered in Azerbaijan [Dunin, 1988]. A re-examination of the diagnostic characters of $N$. laeta has convinced us that actually this species is not conspecific with the generotype of the genus Nigma Lehtinen, 1967 and is more closely related to the genus Ajmonia Caporiacco, 1934. Thus, some taxonomic problems of the Palaearctic group of 'ctenidia-less' Dictynidae, including the genera Ajmonia, Anaxibia Thorell, 1898, Dictynomorpha Spassky, 1939 and Nigma, as well as the position of some Nigma species, are discussed in the present paper as well.

\section{Material and methods}

The type specimens of Dictyna uzbekistanica Charitonov, 1946 ( $(+)$ and Dictyna uzbekistanica vittata Charitonov, 1946 ( $(+)$ that are kept at the collection of Perm State University (Perm, Russia) have been re-examined. The holotype of Dictyna laeta Spassky, 1952 () has not been located in the collection of Zoological Institute (Saint Petersburg, Russia) and seems to have been lost [curator V. Krivokhatsky pers. comm.; December 2016]. New materials of both species were collected in Razavi Khorasan, Tehran and Kurdistan Provinces of Iran.

SEM micrographs were made by means of a Hitachi TM3000 SEM microscope with BSE (back-scattered electrons) at the Perm State University. The terminology of the dictynid palp morphology follows Bond, Opel [1997] and Griswold et al. [2005].

The material treated in the present paper is shared between the collections of the Zoological Museum of the Perm State University (PSU, curator: S.L. Esyunin) and the Zoological Museum of University of Tehran (ZUTC, curator: A. Sari).

The following abbreviations are used in the text: ALE - anterior lateral eyes; AME - anterior median eyes; DiTA - dictynid tegular apophysis; DTA dorsal tibial apophysis; PLE — posterior lateral eyes; $\mathrm{PME}$ - posterior median eyes; RTA — retrolateral tibial apophysis. All measurements are given in millimeters.

\section{Genus Kharitonovia gen.n.}

TYPE SPECIES. Dictyna uzbekistanica Charitonov, 1946, by monotypy.
ETYMOLOGY. The genus name is a patronym honoring the prominent araneologist and the founder of the arachnological school at the Perm State University (Perm, Russia), Dmitry E. Kharitonov (1896-1970), who described the generotype. Gender: feminine.

DIAGNOSIS. The new genus is similar to Emblyna Chamberlin, 1948 and Dictyna in the absence of metatarsal spines and tarsal trichobothria and in having the undivided cribellum, the quadrangular median eye field (Fig. 17), one retro- and three promarginal teeth on chelicerae (Figs 12-13), also in some characteristics of the male palp, viz.: the unmodified cymbium and patella (Fig. 5), the narrow DiTA extended along the retrolateral edge of bulbus (Figs 4, 14), the basal DTA with a pair of ctenidia and the apical RTA (Fig. 16). Kharitonovia gen.n. can be distinguished from the related genera by the conformation of chelicerae, embolus and conductor in the males and especially by the structure of the epigyne and the vulva in the females (Table 1).

DESCRIPTION. Small, carapace brown, abdomen dorsally white or yellow, both covered with white hairs; head raised; eight eyes in two rows (Fig. 17); the anterior eye row slightly recurved and the posterior one clearly recurved in dorsal view; medial eye field transverse-quadrangular; cheliceral furrow with three teeth on the promargin and one small tooth on the retromargin (Figs 11-13); labium triangular; maxillae elongated; leg formula I,II,IV,III; cribellum transverse, undivided; male palp patella non-modified; RTA small with pointed tip (Fig. 16); DTA minute (Figs 5, 16); embolus thin, arc-shaped, with a transparent lateral membrane (Figs 4-5, 14); conductor elongated, with a twisted terminal part (Figs 4-5, 14) and the pelecoid-shaped terminus (Fig. 15); epigyne with two fovea divided by a narrow septum (Figs 1-2, 7, 9); caudal rim of each epigynal fovea transverse and situated near the genital furrow (Figs 1, 7, 9); copulatory ducts broad, hornshaped and situated anteriorly of the spermathecae (Fig. $3)$; spermathecae volute, situated posteriorly of the ducts (Figs 2-3, 7-9).

COMPOSITION. The generotype only, Kharitonovia uzbekistanica (Charitonov, 1946).

DISTRIBUTION. Central Asia: Uzbekistan, northeastern Iran.

Kharitonovia uzbekistanica (Charitonov, 1946), comb.n.

Figs $1-17$.

Dictyna uzbekistanica Charitonov, 1946: 23, fig. 26 (+).

Dictyna uzbekistanica: Charitonov, 1969: 68 (+).

Dictyna uzbekistanica vittata Charitonov, 1946: 23 (†) Syn.n.

Dictyna uzbekistanica vittata: Charitonov, 1969: 68 (†).

TYPES. Holotype of D. uzbekistanica $q$ from Uzbekistan, Qashqadaryo Region, Yakkabog Distr., near $38^{\circ} 58^{\prime} \mathrm{N} 66^{\circ} 40^{\prime} \mathrm{E}$ : body (PSU-7189) labelled as "Dictyna uzbekistanica n. sp. (type!). D. Charitonov det. Yakkabog District, Qashqadaryo Region. 1942. D.M. Fedotov" and the preparation of epigyne (PSU-63-03pr) labelled as "Dictyna uzbekistanica n. sp. D. Charitonov det. Bukhara Region. 1942. D.M. Fedotov".

Holotype of Dictyna uzbekistanica vittata 9 from Uzbekistan, Qashqadaryo Region, Yakkabog Distr.: the body is absent; the 
Table 1. Differences between Kharitonovia gen.n., Emblyna Chamberlin, 1948 and Dictyna Sundevall, 1833. Таблица 1. Различия родов Kharitonovia gen.n., Emblyna Chamberlin, 1948 и Dictyna Sundevall, 1833.

\begin{tabular}{|c|c|c|c|}
\hline Characteristics & Emblyna & Kharitonovia gen.n. & Dictyna \\
\hline Metatarsal trichobothria & $2-3 *$ & $\begin{array}{l}\text { Not found (due to a poor } \\
\text { condition of the studied } \\
\text { specimens) }\end{array}$ & $1(-2 ?)^{*}$ \\
\hline Male cheliceral modification & $\begin{array}{l}\text { External margin convex } \\
\text { medially; central pit broad } \\
\text { (pit diameter = cheliceral } \\
\text { width in the generotype } E \text {. } \\
\text { completa (Chamberlin et } \\
\text { Gertsch, 1929) }\end{array}$ & $\begin{array}{l}\text { External margin direct; } \\
\text { central pit narrow (Fig. 11) }\end{array}$ & $\begin{array}{l}\text { External margin slightly } \\
\text { convex medially; central pit } \\
\text { of moderate width (pit } \\
\text { diameter }=1 / 2 \text { cheliceral width } \\
\text { in the generotype, } D \text {. } \\
\text { arundinacea (Linnaeus, } \\
1758 \text { ) }\end{array}$ \\
\hline Embolic orig in & Basal (-central)* & Basal (Figs 4, 14) & $\begin{array}{l}\text { Basal-subapical* (subapical } \\
\text { in the generotype) }\end{array}$ \\
\hline Embolus & $\begin{array}{l}\text { Typically, thick at base, } \\
\text { gradually enlarged, often } \\
\text { flattened and ribbed, usually } \\
\text { twisted*** }\end{array}$ & $\begin{array}{l}\text { Under compound microscope } \\
\text { it looks } \\
\text { thin and arc-shaped, with a } \\
\text { transparent lateral membrane } \\
\text { (Figs 4-5); yet, under SEM, it } \\
\text { is seen as a flat wide band } \\
\text { (Fig. 14) }\end{array}$ & $\begin{array}{l}\text { Simple slender rod, usually, } \\
\text { quite thin at the base, } \\
\text { gradually acuminate to the } \\
\text { apex*** }\end{array}$ \\
\hline Embolic apex & $\begin{array}{l}\text { Strongly modified*: divided, } \\
\text { incised or otherwise } \\
\text { compl icated*** }\end{array}$ & $\begin{array}{l}\text { Modified: thin, with a lateral } \\
\text { membrane (Fig. 14) }\end{array}$ & Not modified** \\
\hline Terminal part of conductor & $\begin{array}{l}\text { Broad, short (in the } \\
\text { generotype) }\end{array}$ & $\begin{array}{l}\text { Twisted around its axis and } \\
\text { directed backwards (Figs 4-5, } \\
\text { 14) }\end{array}$ & $\begin{array}{l}\text { Twisted around its axis and } \\
\text { directed backwards (in the } \\
\text { generotype) }\end{array}$ \\
\hline Terminus of DiTA & $\begin{array}{l}\text { Hamiform; trans verse (in the } \\
\text { generotype) }\end{array}$ & $\begin{array}{l}\text { Pelecoid-shape; longitudinal } \\
\text { (Fig. 15) }\end{array}$ & $\begin{array}{l}\text { Beak-shaped; longitudinal (in } \\
\text { the generotype) }\end{array}$ \\
\hline Epigyne & $\begin{array}{l}\text { Posterior rim of each } \\
\text { epigynal fovea typically runs } \\
\text { caudad and ectad, being near } \\
\text { to the genital furrow toward } \\
\text { its outer end } * *\end{array}$ & $\begin{array}{l}\text { Caudal rim of each epigynal } \\
\text { fovea transverse, situated } \\
\text { near the genital furrow (Figs } \\
1-2,9 \text { ) }\end{array}$ & $\begin{array}{l}\text { Caudal rim of each epigynal } \\
\text { fovea transverse, situated } \\
\text { near the genital furrow } \\
\text { toward its mesial end }{ }^{* *}\end{array}$ \\
\hline Sclerotized parts of vulva & Poor; compact & Complex (Figs 3, 8) & V-type* \\
\hline Copulatory duct & $\begin{array}{l}\text { Short, relatively direct and } \\
\text { thick }\end{array}$ & $\begin{array}{l}\text { Horn-shaped copulatory ducts } \\
\text { tapered and curved (Fig. } 3 \text { ) }\end{array}$ & $\begin{array}{l}\text { Long and thin, with a spiral- } \\
\text { shaped structure in its } \\
\text { forepart (in the generotype) }\end{array}$ \\
\hline Spermatheca & $\begin{array}{l}\text { Small; oviform } \\
\text { (but after Holm [1945: fig. } \\
\text { 24d], with two types of } \\
\text { receptacula: the small } \\
\text { oviform primary one and the } \\
\text { bigger, geminate secondary } \\
\text { one) }\end{array}$ & $\begin{array}{l}\text { With five convolutions and a } \\
\text { small 'head' (Figs } 2-3,7-9 \text { ) }\end{array}$ & $\begin{array}{l}\text { Small and oviform, with the } \\
\text { additory loculus (in the } \\
\text { generotype) }\end{array}$ \\
\hline
\end{tabular}

preparation of epigyne (PSU-63-04pr) labelled as "Dictyna uzbekistanica n. sp. ab. vittata n. D. Charitonov det. Bukhara Region. 1942. D.M. Fedotov".

Other Material: $10^{7}, 1$ ㅇ (PSU-7230), $10^{7}$ (ZUTC), Iran, Razavi Khorasan Province, Mashhad, X.2014, S. Zamani.

DIAGNOSIS. See under the generic diagnosis.

DESCRIPTION. Holotype female of D. uzbekistanica. Measurements. Total length 3.86. Carapace length 1.23, width 1.05. Eye sizes and interdistances: AME, ALE, PLE 0.07, PME 0.06; AME-AME 0.08, AME-ALE 0.04, PME-PME 0.11, PME-PLE 0.13, AME-PME 0.07, ALE-PLE 0.03. Medial eye field transverse-quadrangular: length 0.17 , width 0.20 anteriorly and 0.24 posteriorly. Clypeus 0.15 , its height 2.1 times smaller than the AME diameter. Chelicera 0.49 long.
Labium length 0.18 , width 0.28 . Maxillae width/length ratio 0.5 (length 0.35 , width 0.18 ). Sternum elongated, width/length ratio 0.8 (length 0.71 , width 0.60 ). Leg measurements are given in Table 2. Calamistrum with 22 setae (Fig. 10). Abdomen almost round (Fig. 6), width/length ratio 0.9 (length 2.63, width 2.30).

Coloration (after Charitonov, [1969: 68-69]). Carapace orange-brown, covered with white thick and long hairs. Sternum orange, with grey-brown edges. Legs yellow; all segments blackened apically. Abdomen oval, slightly depressed dorso-ventrally; dark yellow, with four brown points in its anterior half and a pattern of grey lines (Fig. 6) dorsally, but with a longitudinal dark brown band in the D. uzbekistanica vittata; venter dark yellow. 


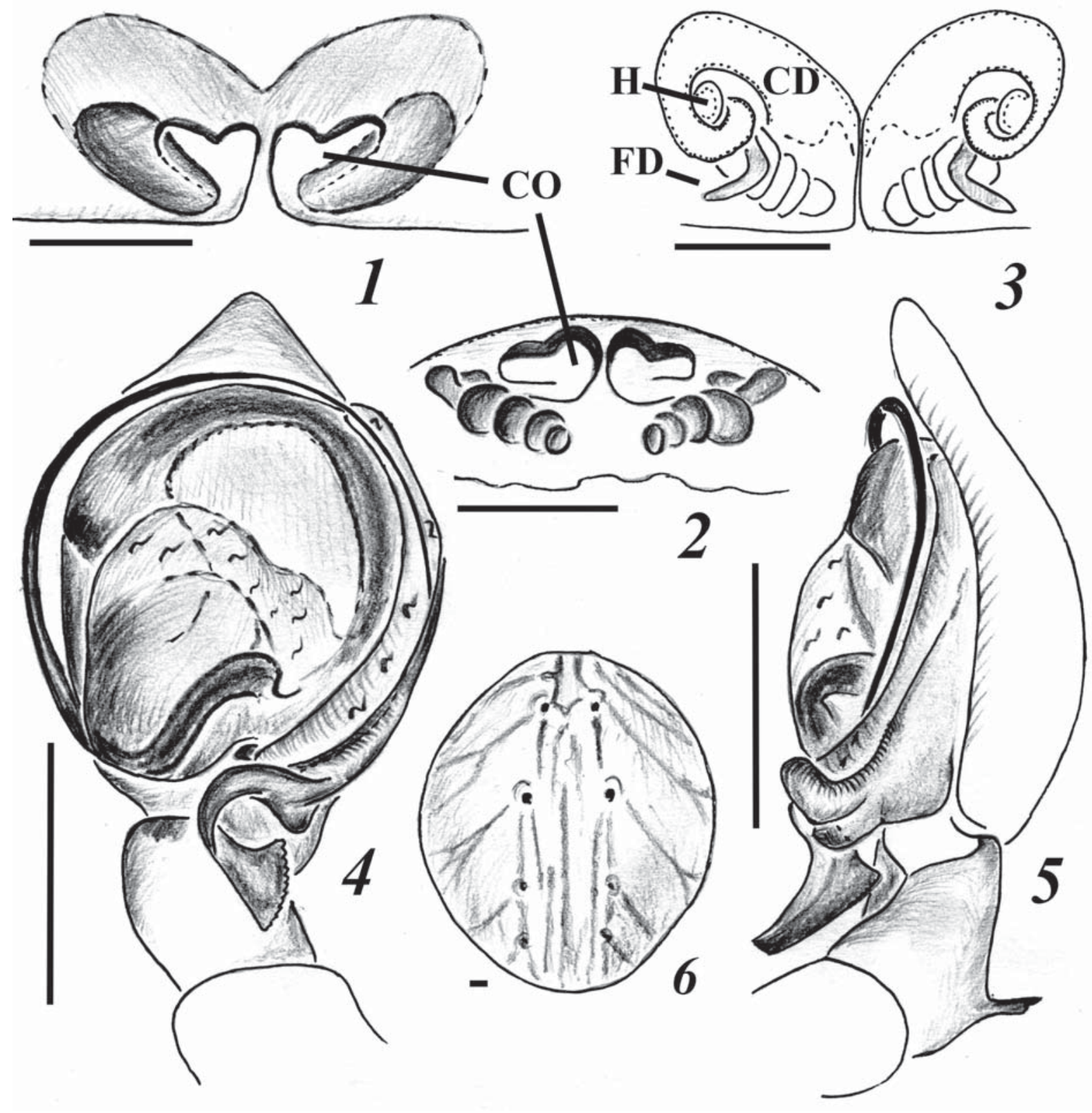

Figs 1-6. Diagnostic characters of Kharitonovia uzbekistanica (Charitonov, 1946) (6 - holotype; 1-5 — Iranian specimens): 1-2 epigyne, ventral and posterior views; 3 - endogyne; $4-5$ - palp, ventral and lateral views; 6 - abdomen, dorsal view. Abbreviations: $C D$ - copulatory duct; $C O$ - copulatory openings; $F D$ - fertilization duct; $H$ - "head" of spermatheca. Scale $=0.1 \mathrm{~mm}$.

Рис. 1-6. Диагностические признаки Kharitonovia uzbekistanica (Charitonov, 1946) (6 - голотип; 1-5 - иранские экземпляры): $1-2$ - эпигина, вид снизу и сзади; 3 - эндогина; $4-5$ - пальп, вид снизу и сбоку; 6 - брюшко, вид сверху. Сокращения: $C D$ - копулятивный канал; $C O$ - копулятивное отверстие; $F D$ - оплодотворительный канал; $H$ - “головка" сперматеки. Масштаб 0,1 мм.

Epigyne (Figs 1-2, 7, 9): two transverse epigynal fovea divided by a narrow septum situated near the genital furrow; the anterior rim of epigynal fovea with a backward projection (Figs 1,9); posterior ones transverse; broad copulatory openings $(C O)$ situated under the anterior rim of epigynal fovea (fig. 1-2). Endogyne (Figs 3,8 ): horn-shaped copulatory ducts $(C D)$ tapered and curved; spermathecae with five convolutions and a small 'head' $(H)$; fertilization ducts $(F D)$ thin and long, extending from the anterior parts of spermathecae, curving and pointing laterally.

Female from Iran. Measurements. Total length 2.98. Carapace length 1.20, width 0.90. Clypeus 0.11 . Chelicera 0.46 long, triangular from inside (Figs 13). Sternum length 0.63 , width 0.58 . Leg formula: I,IV,II,III. Leg measurements are given in Table 3. Calamistrum with 20 setae. Abdomen length 1.78, width 1.70 . 

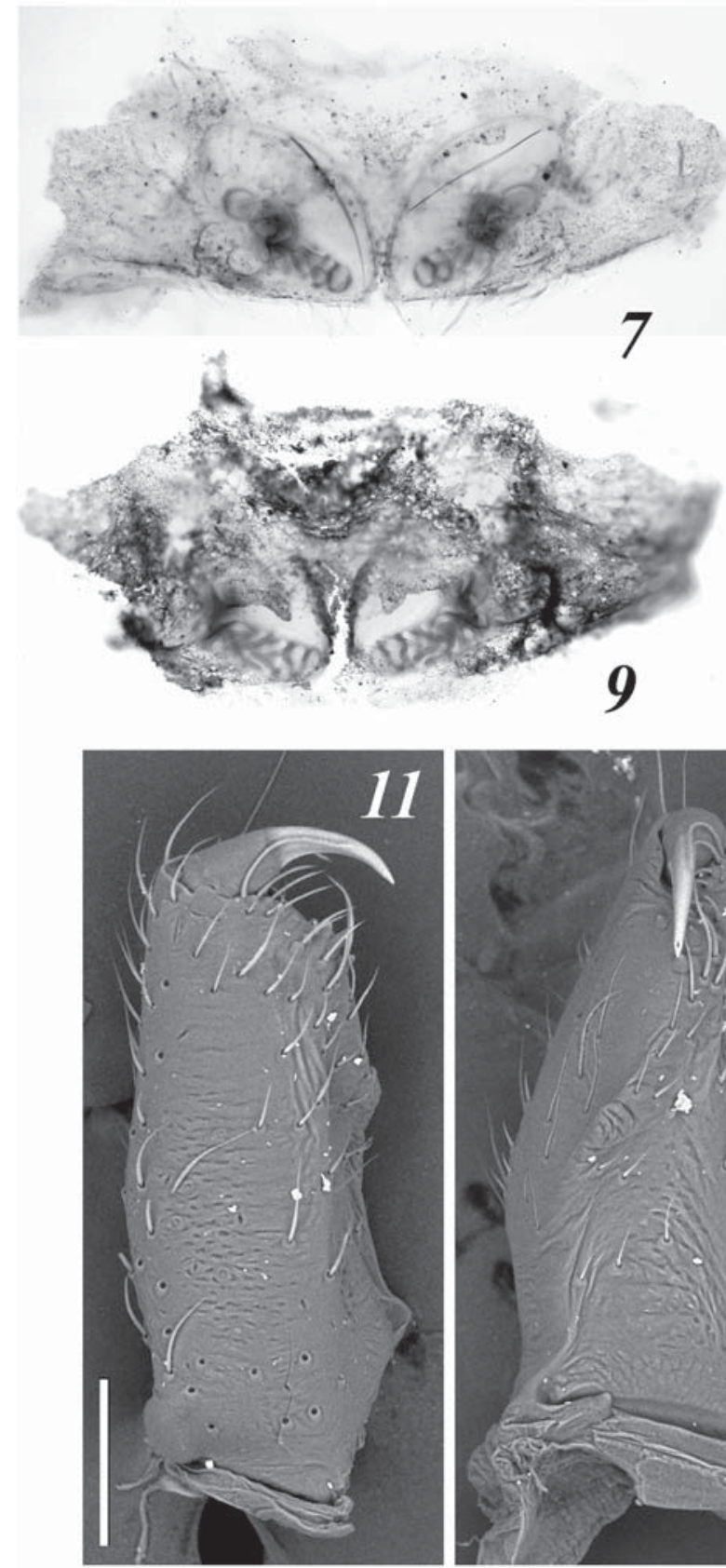
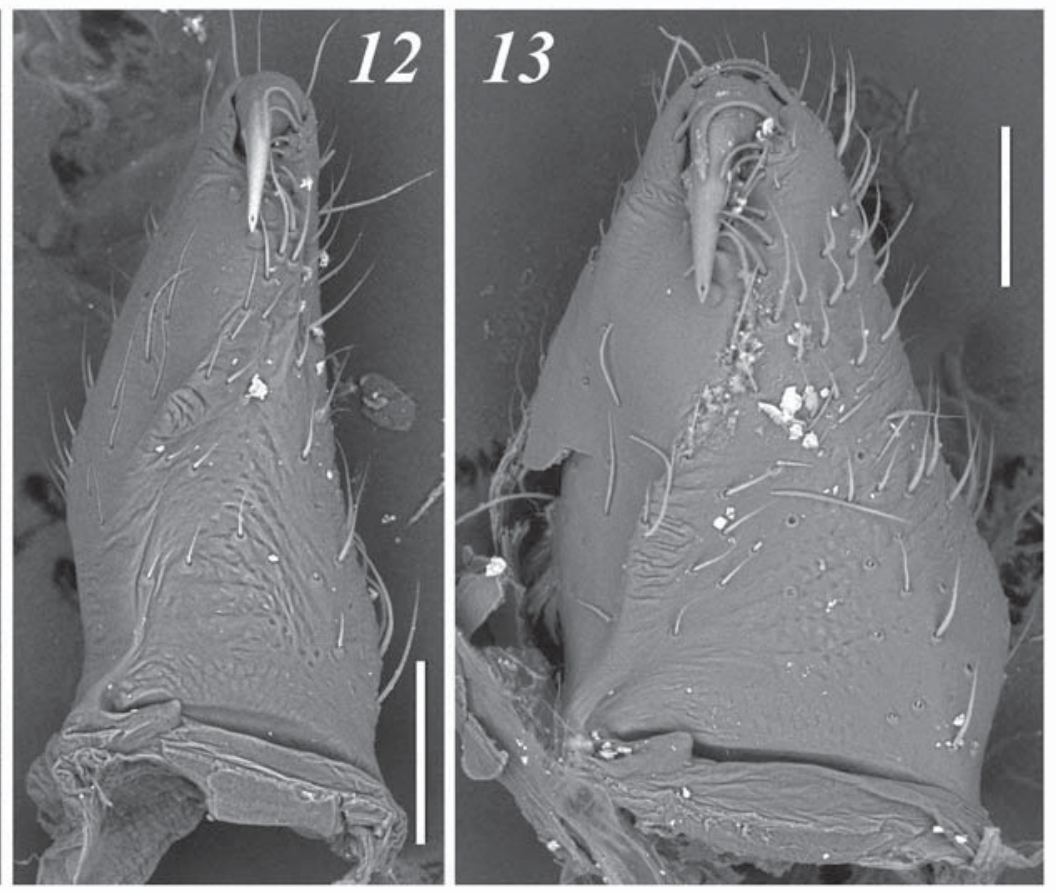

Figs 7-13. Diagnostic characters of Kharitonovia uzbekistanica (Charitonov, 1946) (7-8 - holotype; 9 - holotype Dictyna uzbekistanica vittata; 10-13 - Iranian specimens): 7, 9 - epigyne; 8 - endogyne; 10 - metatarsus and tarsus of IV leg; 11-12 - male chelicera, anteriorly and internally, $13-$ female chelicera, internally. Scale $(10-13)=0.1 \mathrm{~mm}$.

Рис. 7-17. Диагностические признаки Kharitonovia uzbekistanica (Charitonov, 1946) (7-8 — голотип; 9 - голотип Dictyna uzbekistanica vittata; 10-13 - иранские экземпляры): 7, 9 - эпигина; 8 - эндогина; 10 - предлапка и лапка IV ноги; 11-12 хелицера самца, вид спереди и изнутри; 13 - хелицера самки, вид изнутри. Масштаб (10-13) 0,1 мм.

Table 2. Length of leg segments in Kharitonovia uzbekistanica (the holotype).

Таблица 2. Длина ног Kharitonovia uzbekistanica (голотип)

\begin{tabular}{|l|c|c|c|c|c|}
\hline Leg & Femur & Patella+Tibia & Metatarsus & Tarsus & Total length \\
\hline I & 1.03 & 1.10 & 0.68 & 0.48 & 3.28 \\
\hline II & 0.95 & 0.98 & 0.65 & 0.45 & 3.03 \\
\hline III & 0.78 & 0.75 & 0.48 & 0.35 & 2.35 \\
\hline IV & 0.95 & 0.88 & 0.63 & 0.35 & 2.80 \\
\hline
\end{tabular}

Table 3. Length of leg segments of the Iranian specimens of Kharitonovia uzbekistanica $\left(\sigma^{7} / 9\right)$.

Таблица 3. Длина ног иранских экземпляров Kharitonovia uzbekistanica $\left(\sigma^{\top} / P\right)$.

\begin{tabular}{|l|c|c|c|c|c|}
\hline Leg & Femur & Patella+Tibia & Metatarsus & Tarsus & Total length \\
\hline I & $0.70 / 0.90$ & $0.80 / 0.93$ & $0.50 / 0.58$ & $0.30 / 0.40$ & $2.30 / 2.81$ \\
\hline II & $0.68 / 0.83$ & $0.70 / 0.80$ & $0.43 / 0.45$ & $0.30 / 0.35$ & $2.11 / 2.43$ \\
\hline III & $0.50 / 0.65$ & $0.50 / 0.63$ & $0.33 / 0.40$ & $0.23 / 0.30$ & $1.56 / 1.98$ \\
\hline IV & $0.53 / 0.80$ & $0.60 / 0.75$ & $0.40 / 0.55$ & $0.23 / 0.40$ & $1.76 / 2.50$ \\
\hline
\end{tabular}



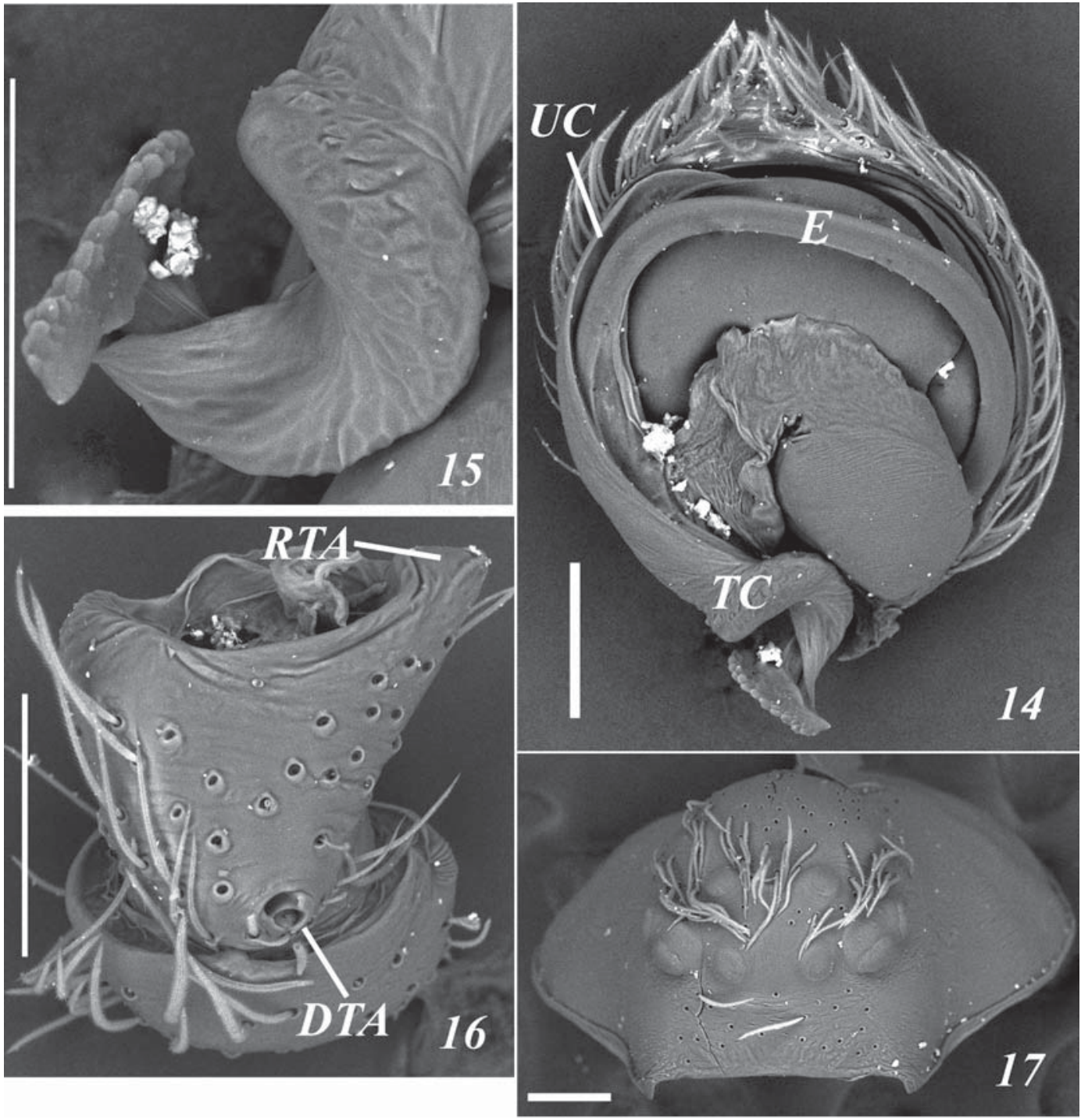

Figs 14-17. Diagnostic characters of the male of Kharitonovia uzbekistanica (Charitonov, 1946): 14 - bulbus, ventral view; 15 terminus of DiTA; 16 - palp tibia, dorsal view; 17 - carapace, anterior view. Abbreviations: DTA — dorsal tibial apophysis; $E-$ embolus; $R T A-$ retrolateral tibial apophysis; $T C$ - terminal part of conductor; $U C$ - upper part of conductor. Scale $=0.1 \mathrm{~mm}$.

Рис. 14-17. Диагностические признаки самца Kharitonovia uzbekistanica (Charitonov, 1946): 14 - бульбус, вид снизу; 15 терминус DiTA; 16 - голень пальпа, вид сверху; 17 - карапакс, вид спереди. Сокращения: DTA - дорсальный отросток голени; $E$ - эмболюс; RTA - заднелатеральный отросток голени; $T C$ и $U C$ - терминальная и вершинная части кондуктора, соответственно. Масштаб 0,1 мм.

Coloration. Carapace black-brown, with white hairs on its head. Chelicera dark brown. Sternum dark brown, with white hairs. Maxillae dark brown, with a white tip. Pedipalp yellow. Legs coloration: femora yellow, blackened basally; patellae and tibiae blackened; metatarsi yellow, blackened apically; tarsi yellow in their basal halves and blackened in the apical halves. Abdomen white, with white thick hairs dorsally; ventrally black, with two white lateral bands. Spinnerets black.

Male from Iran. Measurements. Total length 1.85; carapace length 0.83 , width 0.65 . Eye sizes and interdistances: AME, PME, PLE 0.04, ALE 0.05; AMEAME 0.06, PME-PME 0.07, AME-PME 0.07. Medial eye field almost square (Fig. 17): length 0.14 , width 0.16 anteriorly and posteriorly. Clypeus 0.10 . Cheli- cera 0.4 long, almost rectangular in front view and longer-triangular from inside (Figs 11-12). Cheliceral furrow curved backward. Labium triangular, its maximal width at the base is equal to its length (length, width 0.15 ). Maxillae width/length ratio 0.64 (length 0.22 , width 0.14 ), dark brown, with a white tip. Sternum domelike, its maximal width in the midline is equal to its length (length, width 0.43). Leg segments with dark setae, except for the ventral parts of femora, which are with white setae. Leg measurements are given in Table 3.

Coloration. Carapace pear-shaped, grey-brown, with white hairs on the head. Chelicerae grey-brown. Labium, maxillae, sternum and legs as in the female. Abdomen damaged. 
Palp (Figs 4-5, 14-16): embolic base is situated basally; embolus (or its perceptible part) thin, arc-shaped (Figs 4-5), with a transparent lateral membrane (or a membrane-like part of the embolus); embolus $(E)$ looks as a flat wide band in SEM photos (Fig. 14); narrow DiTA lies laterally, in the range of bulbus; the upper part of conductor (UC; sensu Marusik, Penney [2010]) arcshaped with a groove on its inner side; the terminal part of conductor (TC) twisted around its axis and directed backwards (Figs 4-5, 14); the terminus of DiTA pelecoid-shaped, with multiple denticles situated at its external edge (Fig. 15); male palp patella and palpal tibia not modified; RTA small triangular (Fig. 16); basal DTA minute with a pair of ctenidia (Figs 5, 16).

NOTES. D.E. Kharitonov described a new aberration for one female of Dictyna uzbekistanica from Yakkabog District of Uzbekistan [Charitonov, 1946, 23: ab. vittata; 1969, 68: ab. vittata Charit.]. Based on Articles 45.6.2 and 45.6.4 of the ICZN [1999], this aberration should be treated as a valid subspecies name Dictyna uzbekistanica vittata Charitonov, 1946. According to D.E. Kharitonov, this female differs from the nominative subspecies by the presence of a longitudinal dark brown band on the dorsum [Charitonov, 1946: 23: "Abdomine supra vitta fusca longitudinale marginibus denticulatis ornato"]. No differences were found by D.E. Kharitonov in other somatic characters; yet, we failed to find any differences in the epigyne. Taking into account that the studied specimens of both subspecies were collected from the same locality, it is safe to conclude that both names are to be synonymized.

D. uzbekistanica vittata was overlooked by arachnologists and was not mentioned neither in Roewer's catalogue [Roewer, 1955], nor in the subsequent catalogues by Brignoli [1983], Platnick [1993, 1997 and the internet versions 0 to $15,2000-2014]$, Mikhailov [1997, 2013] and WSC [2016].

POTENTIAL SYNONYMY. According to Charitonov [1969: 68], K. uzbekistanica is closely related to Dictyna cronebergi Simon, 1889 described on the basis of a single female from Mary Province of Turkmenistan. However, Simon [1889: 385] diagnosed the Turkmenian species by its distinct body coloration: yellowred carapace (orange-brown to brown in K. uzbekistan$i c a$ ) and russet abdomen (dark yellow to white in $K$. uzbekistanica), as well as by its smaller size $-2 \mathrm{~mm}$ (3.0-3.9 mm in K. uzbekistanica).

DISTRIBUTION. Central Asia: Qashqadaryo Region of Uzbekistan, Razavi Khorasan Province of Iran [Charitonov, 1946, 1969; present data] (Fig. 30).

“Nigma" laeta (Spassky, 1952)

Figs 18-26, 29.

Dictyna laeta Spassky, 1952: 202, fig. $2(+)$

Dictyna laeta: Andreeva, Tyshchenko, 1969: 378, fig. 4a $\left(\mathrm{O}^{7}\right)$.

Dictyna laeta: Andreeva, 1976: 24, fig. $23\left(\sigma^{7}\right)$.

Nigma laeta: Brignoli, 1983: 515 (transfer from Dictyna)

MATERIAL. Iran: $1 \sigma^{7}$ (PSU-7232), $1 \sigma^{7}$ (ZUTC), Tehran

Province, Damavand County, $35^{\circ} 43^{\prime} \mathrm{N} 52^{\circ} 03^{\prime}$ E, VII.2015, A.
Zamani; $1 \sigma^{7}, 1$ (PSU-7231), Kurdistan Province, Marivan, surroundings of Zarivar Lake, $35^{\circ} 32^{\prime} \mathrm{N} 46^{\circ} 82^{\prime} \mathrm{E}$, VIII.2015, A. Zamani.

DIAGNOSIS. The male of "N." laeta is somewhat similar to that of Nigma shiprai (Tikader, 1966) described from Maharashtra State, India [Tikader, 1966] in the conformation of embolus and terminus of DiTA, as well as in the absence of patellar apophysis, but differs from it in the body coloration: 1) the carapace grey-yellow in " $N$." laeta and brownish red in N. shiprai; 2) the abdomen with a pattern (Fig. 29) in "N." laeta and "whitish, with irregular brown patches" in $N$. shiprai [Tikader, 1966: 48 and fig. 2a]; 3) the abdomen covered with white hairs in $N$. laeta, while with black hairs in N. shiprai.

On the other hand, "N." laeta is close to two species of the genus Ajmonia - A. auritus Song et Lu, 1985 and A. lehtineni Marusik et Koponen, 1998 - in having a transverse pleat on the terminal part of conductor, the tabulate RTA, the incurved distal embolic part (in A. lehtineni only), a pair of lateral epigynal hoods, transverse sclerotized parts of the vulva. It can be distinguished from both related species by (1) the absence of patellar apophysis (present in A. auritus and A. lehtineni [Song, Lu, 1985: fig. 6D; Marusik, Koponen, 1998: fig. 2]), (2) the anterior position of the lateral epigynal hoods (mesial position in A. auritus and A. lehtineni; [Marusik, Esyunin, 2010: figs 1G, 1H; Marusik, Koponen, 1998: fig. 4]) and (3) sclerotized parts of the vulva procurved (recurved in A. auritus and A. lehtineni; [Marusik, Esyunin, 2010: fig. 1I; Marusik, Koponen, 1998: fig. 5]).

See also under "Notes" below.

DESCRIPTION. Male. Small, total length 2.48(2.43-2.53). Carapace length 0.98, width 0.81(0.80-0.83). Carapace pear-shaped, grey-yellow, with white edges on its head. Clypeus 0.07. Chelicera $0.41(0.41-0.42)$ long, grey-yellow, anteriorly with almost parallel sides; triangular-shaped in the lateral view. Cheliceral furrow continued backward, with 3 teeth on the common base on the caudal margin (Fig. 26). Labium grey-yellow, triangled, wider at its base than long, width/length ratio 1.2 (length 0.18 , width 0.21 ). Maxillae elongated, width/length ratio 0.5 (length 0.29 , width $0.15)$, grey-yellow, with a white tip. Sternum pearshaped, length $0.57(0.56-0.57)$, width 0.50 (0.49$0.50)$, grey-yellow, blackened at edges. Legs monochromously grey-yellow. Leg formula: I,II,IV,III. Leg measurements are given in Table 4. Abdomen damaged. "The [dorsal] abdominal pattern is more distinct [as compared to the female $-S . E$.] and is similar to that of $D$ [ictyna ] major" [Andreeva, Tyschenko, 1969: 378].

Table 4. Length of leg segments of Nigma laeta (Spassky, 1952) $\left(\sigma^{7 / 9}\right)$.

Таблица 4. Длина ног Nigma laeta (Spassky, 1952) (Оフ/7).

\begin{tabular}{|l|c|c|c|c|c|}
\hline Leg & Femur & Patella+Tibia & Metatarsus & Tarsus & Total length \\
\hline I & $0.85 / 0.73$ & $1.06 / 0.90$ & $0.54 / 0.45$ & $0.35 / 0.38$ & $2.80 / 2.45$ \\
\hline II & $0.80 / 0.70$ & $0.91 / 0.75$ & $0.50 / 0.40$ & $0.33 / 0.33$ & $2.54 / 2.18$ \\
\hline III & $0.61 / 0.63$ & $0.61 / 0.63$ & $0.40 / 0.33$ & $0.25 / 0.25$ & $1.88 / 1.83$ \\
\hline IV & $0.73 / 0.73$ & $0.78 / 0.80$ & $0.54 / 0.45$ & $0.25 / 0.28$ & $2.29 / 2.25$ \\
\hline
\end{tabular}




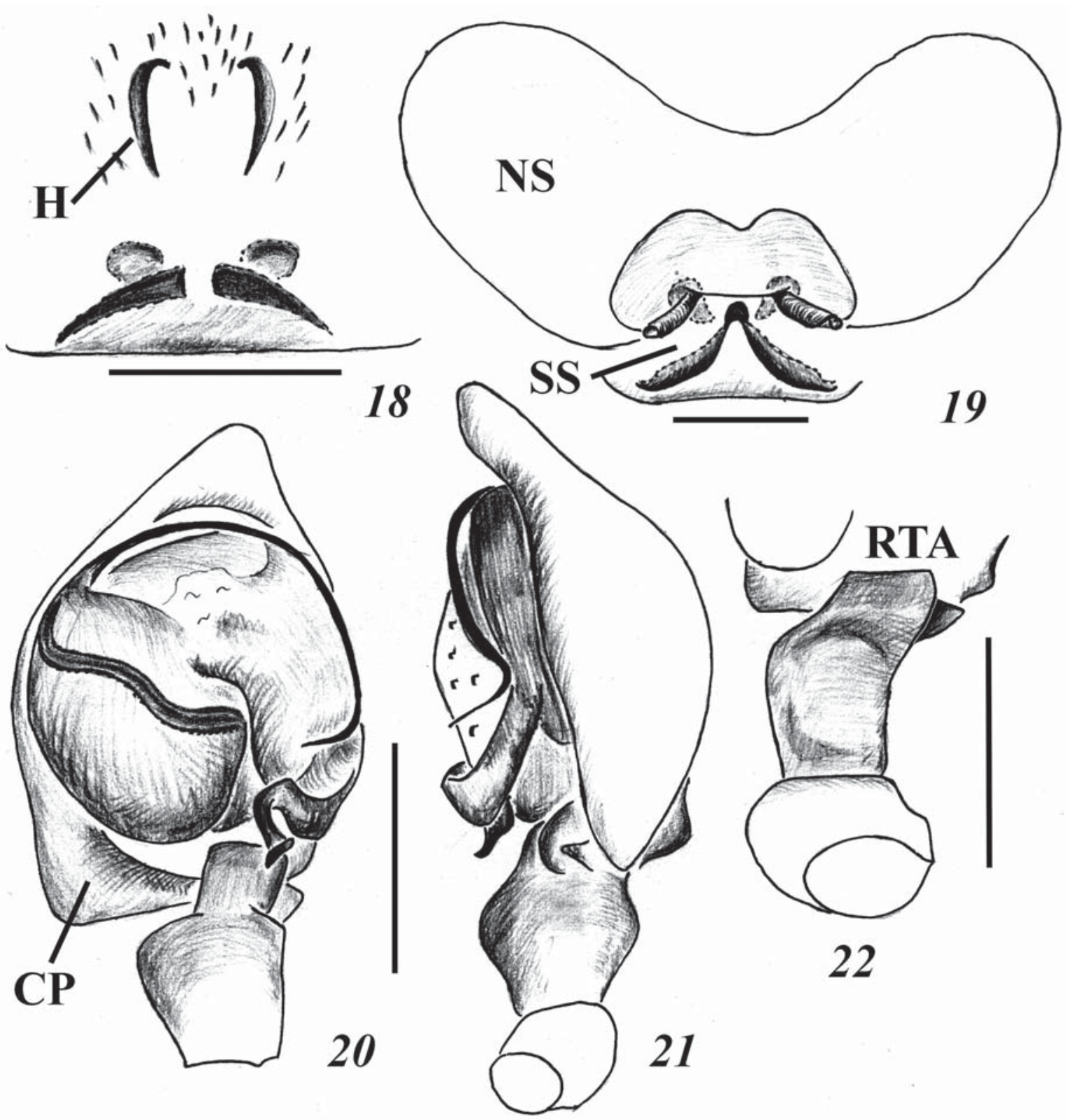

Figs 18-22. Diagnostic characters of "Nigma" laeta (Spassky, 1952): 18 - epigyne, 19 - endogyne; 20-21 - palp, ventral and lateral views; 22 - tibia of male palp, ventrolateral views. Abbreviations: $C P$ — caudal projection of cymbium; $H$ - hoods of epigyne; $N S$ - non-sclerotized structures of spermathecae; RTA - retrolateral tibial apophysis; SS - sclerotized structures of spermathecae. Scale $=0.1 \mathrm{~mm}$.

Рис. 18-22. Диагностические признаки "Nigma” laeta (Spassky, 1952): 18 - эпигина; 19 - эндогина; 20-21 — пальп, вид снизу и сбоку; 22 - голень пальпа самца, вид сбоку-снизу. Сокращения: $C P$ - каудальный выступ цимбиума; $H-$ капюшеновидные складки эпигины; $N S$ - несклеротизованные структуры сперматеки; RTA - заднелатеральный отросток голени; $S S-$ склеротизованные структуры сперматеки. Масштаб 0,1 мм.

Eyes field transverse, its width 2.4 times longer than its length (length 0.15 , width 0.36 ). All eyes of the identical size (0.06); eye interdistances: AME-AME 0.03, PME-PME 0.07, AME-PME 0.01. Medial eye field almost square: length 0.15 , width 0.14 anteriorly and 0.17 posteriorly.

Palp (Figs 20-25): the embolic base is situated subapically; the embolus $(E)$ tape-like on the $2 / 3$ of its basal part and thin the $1 / 3$ of its apical part, with a "hairpin" near its tip (Figs 23-24); the almost oviform DiTA shot and broad; the upper part of conductor (UC) short; the terminal part of conductor (TC) broad, with a transverse pleat (Figs 23, 24); the terminus of DiTA $(T)$ plane, hook-shaped (Fig. 24); patella of male palp unmodified; RTA bifurcated apically (Figs 20, $22,25)$, DTA and ctenidia absent; cymbium with a caudal projection $(C P)$ (Figs 20-21, 23). 

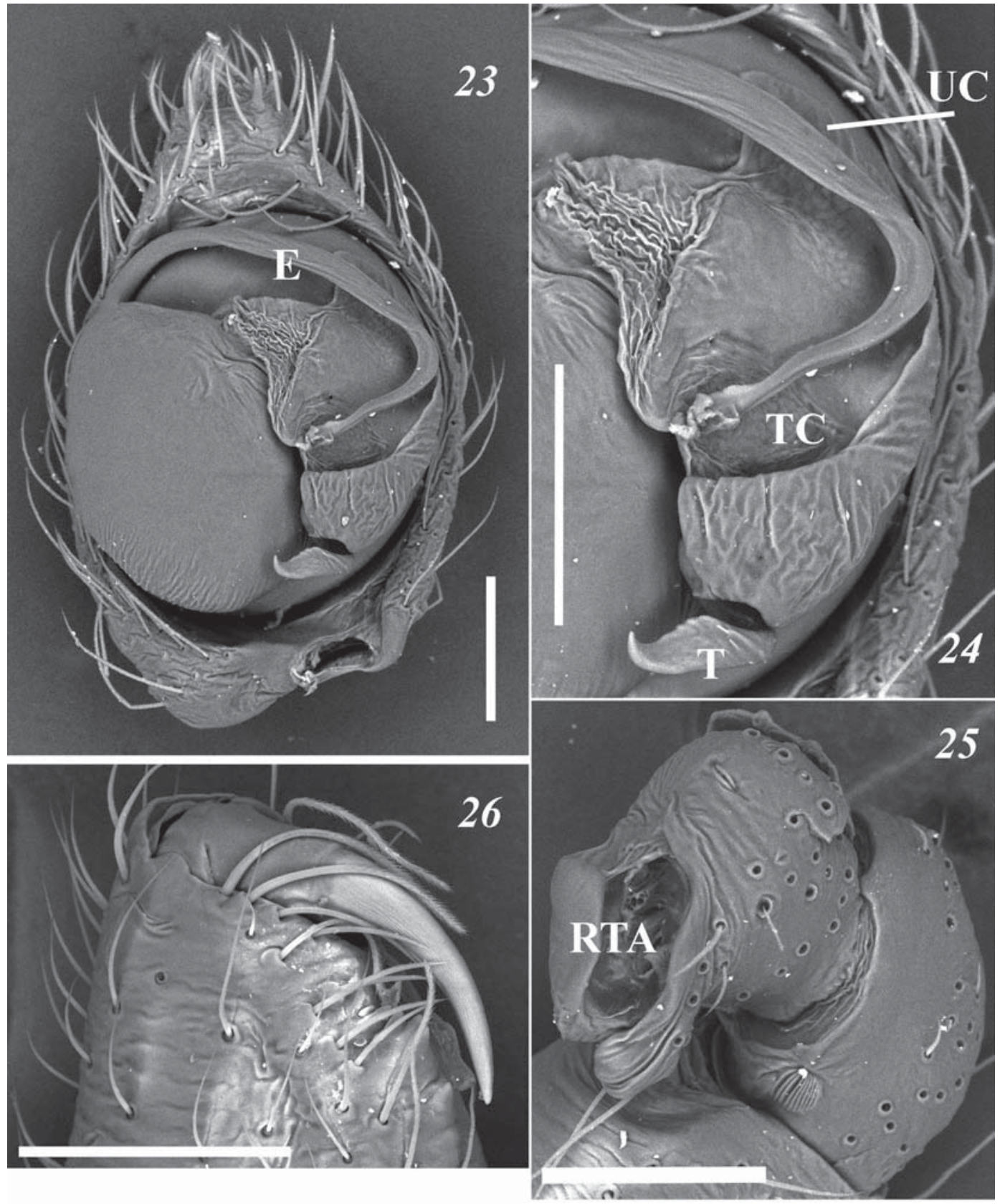

Figs 23-26. Diagnostic characters of the male of "Nigma" laeta (Spassky, 1952): 23 - palp, ventral view; 24 — DiTA and tip of embolus; 25 - tibia of male palp, front view; 26 - tip of chelicera, anteriorly. Abbreviations: $E$ - embolus; $R T A$ - retrolateral tibial apophysis; $T$ - terminus of DiTA; $T C$ - terminal part of conductor; $U C$ - upper part of conductor. Scale $=0.1 \mathrm{~mm}$.

Рис. 23-26. Диагностические признаки самца "Nigma" laeta (Spassky, 1952): 23 - пальп, вид снизу; 24 - DiTA и вершина эмболюса; 25 - голень пальпа, вид спереди; 26 - вершина хелицеры, вид спереди. Аббревиатура: $E$ - эмболюс; RTA заднелатеральный отросток голени; $T$ - терминус DiTA; $T C$ и $U C$ — терминальная и вершинная части кондуктора, соответственно. Масштаб 0,1 мм.

Female. Measurements (the Iranian specimen/Holotype according to Spassky [1952]). Total length 2.85/ 3.25. Carapace length 0.88/1.21, width 0.80/1.05. Carapace dark grey, with light grey lateral margins of the thorax and a median band, covered with white hairs. Clypeus 0.06. Chelicera 0.35 long, light grey. Labium length 0.14 , width 0.20 . Maxillae length 0.27 , width 0.14 . Sternum length 0.52 , width 0.49 . Pedipalps, labi- um, maxillae, sternum and legs light grey. Leg formula: I,IV,II,III. Leg measurements are given in Table 4. Calamistrum with 23 setae.

The Iranian specimen (Fig. 29): abdomen white, with white hairs dorsally and ventrally. Holotype: "dorsum in its anterior third with an indistinct brownish patch, followed by two brown sigillae; the caudal half of dorsum with six pairs of brownish spots" [Spassky, 


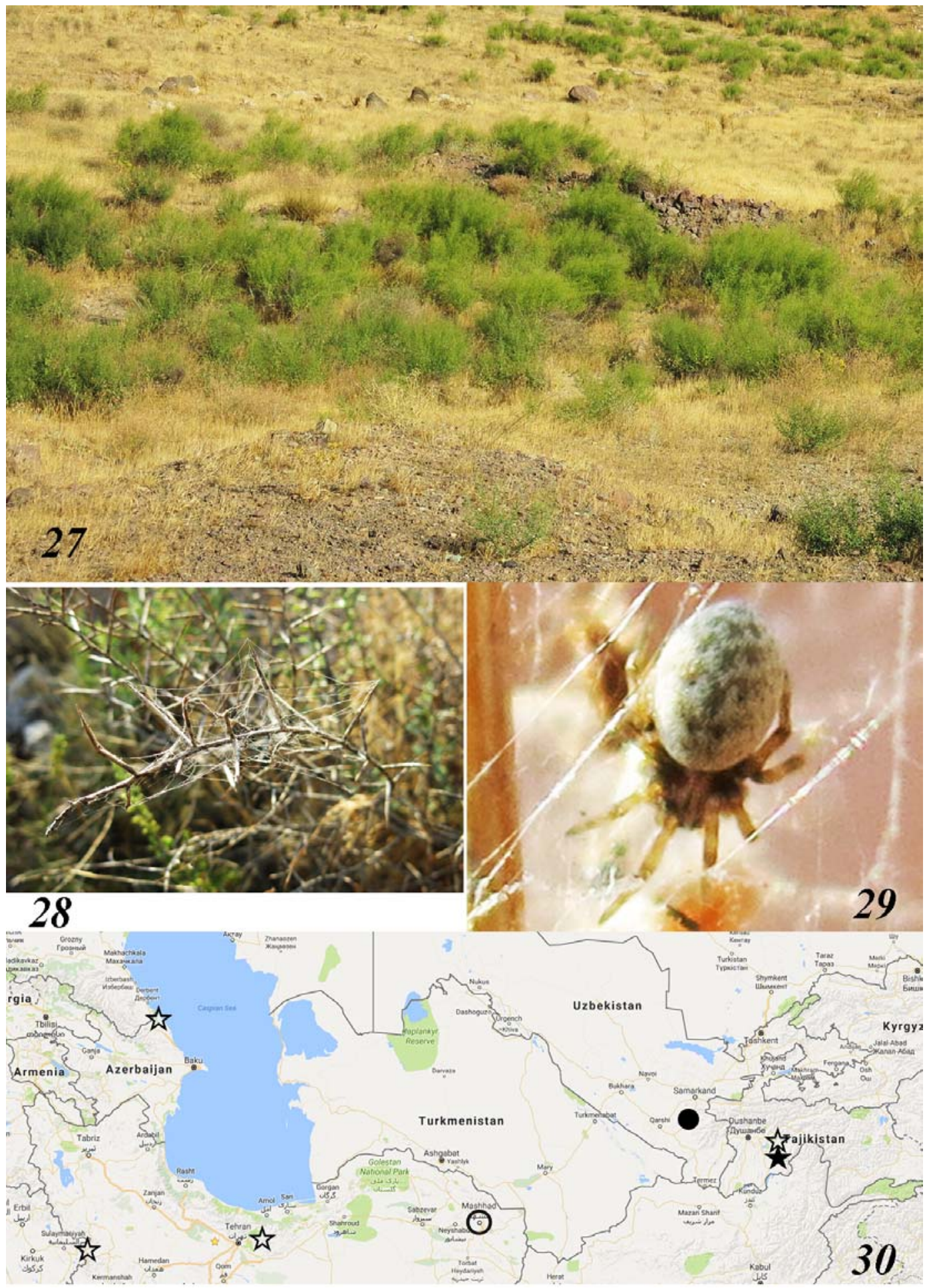

Figs 27-30. Biotope (27), web (28) and habitus (29) of "Nigma" laeta (Spassky, 1952) and map of localities (30). Symbols: asters "N." laeta, circles - Kharitonovia uzbekistanica (Charitonov, 1946); blackened symbols - type localities. Photos by A. Zamani.

Рис. 27-30. Местообитание (27), сеть (28) и внешний вид (29) “Nigma” laeta (Spassky, 1952) и карта распространения (30). Символы: звездочки - “N." laeta, кружки - Kharitonovia uzbekistanica (Charitonov, 1946); зачерненные символы — типовые локалитеты. Фото А. Замани. 
1952: 202]. Cribellum transverse, divided. Spinnerets blackened.

Epigyne (Figs 18) with the two longitudinal parallel hoods $(H)$ only; the fovea absent; the whole epigynal plate is covered with hairs; posteriorly (on the edge of the epigastric furrow) with a pair of sclerotized structures. Endogyne (Fig. 19); with a complex sclerotized part $(S S)$ adjacent to the epigastric furrow and a bigger poorly sclerotized part (NS) extended anteriorly.

NOTES. Nigma laeta was described from Tajikistan in the genus Dictyna. It was synonymized by Lehtinen [1967: 252] with Nigma walckenaeri (Roewer, 1951). Having mentioned the "uncertain synonymy", Brignoli [1983: 515] proposed a new combination, Nigma laeta (Spassky, 1952), which was accepted by the WSC [2016]. It is worth mentioning that Dunin [1988: 197], who studied the female from Azerbaijan which is absent from his collection retained at the Zoological Museum of the Moscow University [K.G. Mikhailov, pers. com.], proposed a combination of $N$. laeta irrespective of Brignoli's opinion. Yet, in our opinion, this species has little in common with true members of the genus Nigma (Table 5).

Thus, it is necessary to stress upon that the assignment of this species to the genus Nigma is erroneous. By some characteristics, such as the reduced male cribellum, the fused bases of prolateral teeth of the cheliceral furrow, the armament of metatarsi III-IV, the shape of the cymbial modification, the conductor and the terminus DiTA, "N." laeta resembles some species of Ajmonia, but it strongly differs from its generotype (see below under "Taxonomic remarks" for further details).

As clear from the aforementioned discussion (see also Table 5), "Nigma" laeta is to be treated as insertae sedis. It is also possible that it is related to $N$. shiprai, and both these species compose a separate genus closely related to Ajmonia.

DISTRIBUTION (Fig. 30). Azerbaijan: Khachmaz

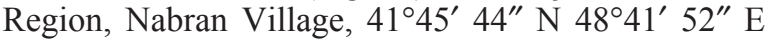
[Dunin, 1988]. Tajikistan: described from Mu'minobod of Khatlon Region, $38^{\circ} 08^{\prime} \mathrm{N} 70^{\circ} 02^{\prime} \mathrm{E}$ by two females [Spassky, 1952]; male collected together with females described from Khozretishi Range, c. $10 \mathrm{~km}$ of Mu'minobod $38^{\circ} 15^{\prime} 00^{\prime \prime} \mathrm{N} 70^{\circ} 12^{\prime} 42^{\prime \prime} \mathrm{E}$ [Andreeva, Tyschchenko, 1969; Andreeva, 1976]. Iran: from Kurdistan and Tehran provinces [present data].

\section{Taxonomic remarks}

The Palaearctic group of "ctenidia-less" Dictynidae, including the genera Ajmonia Caporiacco, 1934, Anaxibia Thorell, 1898, Dictynomorpha Spassky, 1939 and Nigma Lehtinen, 1967, in our opinion, requires a thorough taxonomic revision by applying modern approaches and by studying all diagnostic characters. At present, the state of knowledge of these genera is as follows.

Genus Anaxibia. The generotype of Anaxibia remains known from the original description only; it has never been illustrated and its male is yet unknown. Other five species included in this genus by Lehtinen [1967] remain known from the original descriptions only [WSC, 2016]. The genus Anaxibia seems to be well isolated from other related genera and can be distinguished by the following characters (sensu Lehtinen [1967]): (1) long to very long spinnerets and (2) the reduced cribellum.

Genera Ajmonia and Dictynomorpha. Ajmonia was described as a monotypic genus from Karakorum (2200-3200 m a.s.1.) [Caporiacco, 1934]. The type species - Ajmonia patellaris Caporiacco, 1934 was synonymized by Lehtinen [1967] with Ajmonia velifera (Simon, 1906) described from the Himalayas (State Sikkim, India) [Simon, 1906: sub Dictyna]. In the same work, Lehtinen [1967] also synonymized Dictyna yunnanensis Schenkel, 1963 from Yunnan Province of China [Schenkel, 1963] with A. velifera. Since the publication by Lehtinen [1967], this genus has never been revised and currently includes nine valid species [WSC, 2016].

The genus Dictynomorpha was originally described as monotypic, with the generotype being Dictynomorpha strandi Spassky, 1939 from Kyrgyzstan. The latest taxonomic revision of the genus was conducted by Marusik et al. [2015], who argued that the genus would contain two species: D. strandi and D. daemons Marusik, Esyunin et Tuneva, 2015.

Although Lehtinen [1967] treated Dictynomorpha and Nigma as independent genera in his monograph, he also doubted whether they better be "considered the subgenera of Ajmonia".

In our opinion, the generotypes of Dictynomorpha and Ajmonia, as well as A. psitacea (Schenkel, 1936) and $D$. daemons, have no shared generic diagnostic characters (cf. [Caporiacco, 1934: fig. 6; Spassky, 1938: figs 1-2; Marusik, Esyunin, 2010: fig. 3A-C; Marusik et al., 2015: figs 10-13, 16-19]). Males of these four species are characterized by the strongly modified cymbium (with a massive extension process and a spur), patella (with two or three dorsal processes; except for A. psitacea having a single process) and tibia (with two apophyses). Yet, we do not know the structure of the epigyne and endogyne in $A$. velifer, neither in A. psitacea and $D$. daemons. Therefore, it is better to postpone the establishment of new combinations until both sexes of these species have been collected and studied.

Males of several other species included in the genus Ajmonia (A. auritus Song et Lu, 1985, A. capucina (Schenkel, 1936), A. lehtineni Marusik et Koponen, 1998, A. marakata (Sherriffs, 1927), A. patellaris (Simon, 1911)) differ significantly from the generotype in having an exiguous modification of the cymbium (a small extension or a process) and the single lateral patellar process. However, by other important diagnostic characteristics, the aforementioned group of species is not homogeneous. For example, the cymbial apophysis of $A$. patellaris is directed forward (in all other species of Ajmonia and Dictynomorpha, the caudal 
Table 5. A comparison of "Nigma" laeta and the genus Nigma Lehtinen, 1967. Таблица 5. Сравнение "Nigma" laeta и рода Nigma Lehtinen, 1967.

\begin{tabular}{|c|c|c|}
\hline Characters & Nigma & "Nigma" laeta \\
\hline Cribellum & $\begin{array}{l}\text { In both sexes, well developed and usually } \\
\text { divided (sometimes quite ind istinctly divided)** }\end{array}$ & $\begin{array}{l}\text { Female: divided } \\
\text { Male: small, undivided }\end{array}$ \\
\hline Calamistrum & $\begin{array}{l}32 \text { setae (in the generotype, } N . \text { walckenaeri } \\
\text { (Roewer, 1951) }\end{array}$ & 23 setae \\
\hline Cheliceral teeth & $1+3-5^{*}$ & $\begin{array}{l}0+3 \text {; the bases of prolateral teeth are fused } \\
\text { (Fig. 26) }\end{array}$ \\
\hline $\begin{array}{l}\text { Male cheliceral } \\
\text { modification }\end{array}$ & $\begin{array}{l}\text { Anteriorly in the basal half with a blunt - usually } \\
\text { medial - outgrowth or ledge, medially not } \\
\text { diverging** }\end{array}$ & Anterobasal ledge; medially not diverging \\
\hline Shape of medial eye field & Trapezoidal & Square \\
\hline Metatarsal spines & $\begin{array}{l}\text { None* } \\
\text { Leg bristles absent** }\end{array}$ & $\begin{array}{l}\text { Metatarsi III-IV with a pair of ventral } \\
\text { apical spines }\end{array}$ \\
\hline Cymbium & Usually, with a probasal hook or outgrowth** & Caudal projection (Figs $20-21,23$ ) \\
\hline Tibial processes & With a retrodistal outgrowth** & With a latero-apical bifurcate lobe (Fig. 25) \\
\hline Patella & With a retrodorsal outgrowth or hook** & Unmodified (Figs 21, 25) \\
\hline Originating of embolus & Lateral & Subapical (Figs 20, 23) \\
\hline Embolus & $\begin{array}{l}\text { Thin; flagelliformis; lies along bulbus border; } \\
\text { distal part directed backwards }\end{array}$ & $\begin{array}{l}\text { Tape-like in the } 2 / 3 \text { of its basal part and thin } \\
\text { in the } 1 / 3 \text { of its distal part; situated in the } \\
\text { anterior half of the bulbus; distal part } \\
\text { curved in wards to the center of bulbus (Figs } \\
23-24 \text { ) }\end{array}$ \\
\hline Embolic apex & Thick, with a small hook* & Thick, simple (Figs 21, 24) \\
\hline $\begin{array}{l}\text { Dictynid terminal apophysis } \\
\text { (DiTA) }\end{array}$ & $\begin{array}{l}\text { Narrow, lines along the palpal axis; extending } \\
\text { beyond the posterior edge of the bulbus }\end{array}$ & $\begin{array}{l}\text { Broad; situated laterally, within the edges of } \\
\text { the bulbus (Fig. 23) }\end{array}$ \\
\hline Conductor & $\begin{array}{l}\text { The upper part elongate (short in N. tuberosa) } \\
\text { The terminal part elongate }\end{array}$ & $\begin{array}{l}\text { The upper part short } \\
\text { The terminal part broad, with a transverse } \\
\text { pleat }\end{array}$ \\
\hline Terminus of DiTA & Helical (digital in N.tuberosa) & Hook-shaped \\
\hline $\begin{array}{l}\text { Non-sclerotized parts of } \\
\text { vulva (the "anterior } \\
\text { structure", according to } \\
\text { Wunderlich }[2011] \text { ) }\end{array}$ & More or less oval, converging anteriorly & Round, spaced out \\
\hline Sclerotized parts of vulva & With a )(-shaped longitudinal structure & $\begin{array}{l}\text { With a transverse structure, which is } \\
\text { procurved in its middle part }\end{array}$ \\
\hline Opisthosomal colour & Mainly or partly greenish** & Grey \\
\hline
\end{tabular}

projection or apophysis is directed upward or backward); the palpal tibia of $A$. marakata possesses a dorsal projection, as in Nigma puella (Simon, 1870); the embolic shape and DiTA of A. capucina are typical of those in the genus Nigma; the distal part of the embolus in A. lehtineni is bent inward to the center of bulbus as in D. daemonis, $N$. shiprai and "N." laeta.

Genus Nigma. The genus Nigma, with the generotype $N$.flavescens (Walckenaer, 1830), was established by Lehtinen [1967] as a substitution name for Heterodictyna Dahl, 1924. At that time the genus included ten species (including some unaccepted synonyms). At present, the genus includes 13 valid species [WSC, 2016; Esyunin, Sozontov, 2016]. The taxonomic independence of the six European species of Nigma (viz., N. flavescens, N. gratiosa (Simon, 1881), N. hortensis (Simon, 1870), N. puella (Simon, 1870), N. tuberosa Wunderlich, 1987 and N. walckenaeri (Roewer, 1951)), was recently justified by Wunderlich [2011]. In our opinion, the assignment of other seven species to the genus Nigma is poorly justified. Some of the taxonom- ic problems related to these species are discussed below.

Based on the original descriptions, four Nigma species are to be treated as insertae sedis.

1. "Nigma" conducens (O. Pickard-Cambridge, 1876)

Dictyna conducens O. Pickard-Cambridge, 1876: 556, Pl. 58, fig. $3\left(0^{7}\right)$.

Nigma conducens: Lehtinen, 1967: 252, figs 329, 331 ( ( $0^{7}+$ ).

COMMENTS. Dictyna conducens was described by Pickard-Cambridge [1876] from Egypt. Lehtinen [1967: 252] proposed a new combination Nigma conducens. However, the species differs from other Nigma (s.str.) species by the following diagnostic characters: the basal (not lateral) origin of the embolus [Lehtinen, 1967: fig. 331]; the absence of lateral chalk bands on carapace [Pickard-Cambridge, 1876: 556] (present in Nigma); the hamiform terminus of DiTA [Lehtinen, 1967: fig. 331] (helical in Nigma); and the presence of two epigynal foveae divided by a wide septum [Pickard-Cambridge, 1876: fig. 3g; Lehtinen, 1967: fig. 329] 
(foveae are indistinct in Nigma). According to the original observation by Pickard-Cambridge [1876: 556], "this species is very nearly allied to the next, D. condocta [SE: Archaeodictyna condocta (O. Pickard-Cambridge, 1876)], resembling it closely in colors and in the general character of its marking". The conformation of the male palp (the basal origin and shape of the embolus, as well as the origin and shape of DiTA (see Lehtinen [1967: fig. 325]) and the epigyne (two foveae; see Tullgren [1910, fig. 4a] and Lehtinen [1967: fig. 333]) are also evidence that $N$. conducens is close to $A$. condocta. At the same time, both these species are not related to Archaeodictyna anguiniceps (Simon, 1899) — the generotype of Archaeodictyna Caporiacco, 1928 - and thus do not belong to the latter genus. The establishment of a new combination for $N$. conducens is postponed until the type material has been re-examined.

2. "Nigma" laeta (Spassky, 1952)

COMMENTS. See above under "Notes" to "Nigma" laeta.

3. "Nigma" linsdalei (Chamberlin et Gertsch, 1958)

Heterodictyna linsdalei Chamberlin, Gertsch, 1958: 47, Pl.10, figs 3-13 $\left(\mathrm{O}^{7}+\right.$ + $)$

Nigma linsdalei: Griswold et al., 2005: 21, fig. 176A (O')

COMMENTS. Heterodictyna linsdalei was described by Chamberlin and Gertsch [1958] from California. It was "provisionally listed" by Lehtinen [1967: $210]$ in the genus Ajmonia, but with the remark "although it may belong to Dictynomorpha" [lbid.]. Brignoli [1983: 515] did not accept Lehtinen's proposal and suggested a new combination Nigma linsdalei, which was then accepted by WSC [2016]. However, "N." linsdalei differs from other congeners of the genus Nigma (s.str.) by the following characters: (1) the absence of marginal white bands of the head (a series of white spots separated from margins present in " $N$." linsdalei; [Chamberlin, Gertsch, 1958: figs 8, 13]) and greenish coloration of the carapace; (2) the cymbium modification, viz., "elevated to a rounded ridge which is shallowly excavated on the prolateral side" in " $N$." linsdalei [Chamberlin, Gertsch, 1958: 48 and fig. 9] vs. non modified "usually with a probasal hook or outgrowth" in Nigma [Wunderlich, 2011: 312]; (3) the modification of the male palp tibia, which is "with an elevated carina above and a small tooth on the prolateral edge" in "N." linsdalei [Chamberlin, Gertsch, 1958: 48; Griswold et al., 2005: fig. 176A] vs. with "a retrodistal outgrowth" in Nigma [Wunderlich, 2011: 312, figs 10-14]; (4) "epigyne a low elevation with a pair of round, very shallow, and indistinct atria separated by a broad septum" in "N." linsdalei [Chamberlin, Gertsch, 1958: 48] vs. with an indistinct fovea in Nigma; and finally (5) "chelicerae anteriorly in the basal half with a blunt outgrowth or ledge" in Nigma (s.str.) [Wunderlich, 2011: 312, figs 4-6]) vs. no modification of the male chelicerae in " $N$." linsdalei.

The male of " $N$." linsdalei is similar to those of some Ajmonia species, such as A. capucina, A. lehtine$n i, A$. psittacea, which are characterized by the pres- ence of lateral patellar apophysis of the male palp, but differs from them in (a) the shape of this apophysis possessing a "conspicuous long lobe" in " $N$." linsdalei [Chamberlin, Gertsch, 1958: 48, figs 9, 12; Griswold et al., 2005: fig. 176A] vs. tabulate in A. capucina and $A$. psittacea or short claw-shaped in A. lehtineni and, what is more important, (b) in having the modification of palpal tibia in "N." linsdalei (see above under the point 3), which is absent from Ajmonia species.

4. "Nigma" longipes (Berland, 1914)

Dictyna longipes Berland, 1914, 55, figs 12-18 ( ( 7 \% $)$

D. longipes: Caporiacco, 1949, 325, fig. 4a-b ( $\mathrm{O}^{\mathrm{T}}+$ )

COMMENTS. Dictyna longipes was described by Berland [1914] from Kenya. A new combination Nigma longipes was proposed by Lehtinen [1967: 252]. However, the species is characterized by paired ctenidia on the tibial projection (absent from Nigma) and the large DiTA coming back at the patella [Berland, 1914: fig. 14-16], as well as by the absence of a white marginal band on the head and an anterior outgrowth or ledge on the basal half of male chelicerae, which are typical of Nigma (s.str.).

ACKNOWLEDGMENTS. The authors are grateful to the Head of the Zoological Museum of the Perm State University, A.V. Grischenko, for allowing us to use the Museum's SEM facilities. Special thanks go to Dmitri V. Logunov (Manchester, UK) for commenting on the manuscript and for editing the English of the final draft.

\section{References}

Andreeva E.M. 1976. [Spiders of Tajikistan. The fauna and zonalecological distribution]. Dushanbe: Donish. 193 p. [in Russian]

Andreeva E.M., Tyshchenko V.P. 1969. [Materials on the spider fauna of Tajikistan. I. Haplogynae, Cribellatae, Ecribellatae, Trionychae (Pholcidae, Palpimanidae, Hersiliidae, Oxyopidae)] // Entomologicheskoe obozrenie. Vol.48. No.2. P.373-384 [in Russian].

Berland L. 1914. Araneae (1re partie) // Voyage de Ch. Alluaud et R. Jeannel en Afrique oriental (1911-1912): Résultats scientifiques. Paris. Vol.3. P.37-94.

Brignoli P.M. 1983. A catalogue of the Araneae described between 1940 and 1981. Manchester Univ. Press. 755 p.

Bond J.E., Opell B.D. 1997. Systematics of the spider genera Mallos and Mexitlia (Araneae, Dictynidae) // Zoological Journal of the Linnean Society. Vol.119. P.389-445.

Caporiacco L., di 1934. Aracnidi dell'Himalaia e del Karakoram raccolti dalla Missione Italiana al Karakoram (1929-VII) // Memorie della Società Entomologica Italiana, Genova. Vol.13. P.113-160.

Caporiacco L., di. 1949. Aracnidi della colonia del Kenya raccolti da Toschi e Meneghetti negli anni 1944-1946 // Commentationes Pontificia Academia Scientiarum. Vol.13. P.309-492.

Chamberlin R.V. 1948. The genera of North American Dictynidae // Bulletin of the University of Utah. Vol.38. No.15. P.1-31.

Chamberlin R.V., Gertsch W.J. 1958. The spider family Dictynidae in America north of Mexico // Bulletin of the American Museum of Natural History. Vol.116. P.1-152.

Charitonov D.E. 1946. [New forms of spiders of the USSR] // Izvestija Estestvenno-Nauchnogo Instituta pri Molotovskom Gosudarstvennom Universitete. Vol.12. P.19-32 [in Russian].

Charitonov D.E. 1969. [Materials to spider fauna of USSR] // Uchenye Zapiski, Permskij Gosudarstvennyj Universitet. No.179. P.59-133 [in Russian]. 
Dunin P.M. 1988. [Cribellate spiders (Aranei, Cribellatae) of Azerbaijan] // Entomologicheskoe Obozrenie. Vol.57. No.1. P.373384 [in Russian].

Esyunin S.L., Sozontov A.N. 2016. On a new Eurasian species of Dictyna Sundevall 1833 (Aranei, Dictynidae) with taxonomic notes on poorly known Palaearctic Dictyna species // Arthropoda Selecta. Vol.25. No.2. P.199-206.

Griswold C.E., Ramírez M.J., Coddington J.A., Platnick N.I. 2005 Atlas of phylogenetic data for entelegyne spiders (Araneae: Araneomorphae: Entelegynae) with comments on their phylogeny // Proceedings of the California Academy of Sciences. Vol.56. Suppl.2. P.1-324.

International Code of Zoological Nomenclature (Fourth Edition) 1999. London: International Trust for Zoological Nomenclature, The Natural History Museum. 306 p.

Jocqué R., Dippenaar-Schoeman A.S. 2006. Spider Families of the World. Tervuren: Musée Royal de 1'Afrique Central. 336 p.

Lehtinen P.T. 1967. Classification of the cribellate spiders and some allied families, with notes on the evolution of the suborder Araneomorpha // Annales Zoologici Fennici. Vol.4. No.3. P.199-468.

Marusik Yu.M., Esyunin S.L. 2010. On the northernmost Ajmonia Caporiacco, 1934 (Aranei: Dictynidae: Dictyninae) // Journal of Natural History. Vol.44. No.5/6. P.361-367.

Marusik Yu.M., Esyunin S.L., Tuneva T.K. 2015. A survey of Palaearctic Dictynidae (Araneae). 1. Taxonomic notes on Dictynomorpha Spassky, 1939, Brigittea Lehtinen, 1967 and Lathys Simon, 1884 // Zootaxa. Vol.3925. No.1. P.129-144.

Marusik Y.M., Koponen S. 1998. New and little known spiders of the subfamily Dictyninae (Araneae: Dictynidae) from south Siberia // Entomological Problems. Vol.29. P.79-86.

Marusik Yu.M., Penney D. 2010. Conformation of the male palp in some spiders belonging to the RTA-clade and problems in taxonomy // Book of Abstracts. 18th International Congress of Arachnology. Siedlce. P.272-276.

Mikhailov K.G. 1997. Catalogue of the spiders of the territories of the former Soviet Union (Arachnida, Aranei). Moscow: Zoological Museum of Moscow State University Press. 416 p.

Mikhailov K.G. 2013. Spiders (Arachnida: Aranei) of Russia and adjacent countries: a non-annotated checklist // Arthropoda Selecta. Suppl.3. P.1-262.

Pickard-Cambridge O. 1876. Catalogue of a collection of spiders made in Egypt, with descriptions of new species and characters of a new genus // Proceedings of the Zoological Society of London. Vol.36. P.541-630.
Platnick N.I. 1993. Advances in spider taxonomy 1988-1991. With synonymies and transfers 1940-1980. New York. 846p.

Platnick N.I. 1997. Advances in spider taxonomy 1992-1995. With redescriptions 1940-1980. New York. 976p.

Platnick N.I. 2014. The World Spider Catalog, version 15. New York: American Museum of Natural History. Available at http:/ /research.amnh.org/entomology/spiders/catalog/index.html (accessed 28 August 2014).

Roewer C.F. 1955. Katalog der Araneae von 1758 bis 1940. Bruxelles. Bd.2. $1751 \mathrm{~S}$

Schenkel E. 1963. Ostasiatische Spinnen aus dem Muséum d'Histoire naturelle de Paris // Mémoires du Muséum National d'Histoire Naturelle de Paris. Vol.25. S.1-481.

Simon E. 1889. Arachnidae transcaspicae ab ill. Dr. G. Radde, Dr. A. Walter et A. Conchin inventae (annis 1886-1887) // Verhandlungen der Kaiserlich-Königlichen Zoologisch-Botanischen Gesellschaft in Wien. Bn.39. S.373-386.

Simon E. 1906. Etude sur les araignées de la section des cribellates // Annales de la Société Entomologique de Belgique. Vol.50. P.284-308

Song D.X., Lu L. 1985. On some dictynids from China (Araneae: Dictynidae) // Sinozoologia. Vol.3. P.77-83.

Spassky S. 1952. [Spiders of Turan Zoogeographical Province] // Entomologicheskoe Obozrenie. Vol.32. P.192-205 [in Russian].

Tikader B.K. 1966. Studies on some spiders of the genus Dictyna (family: Dictynidae) from India // Proceedings of the Linnean Society of London. Vol.177. No.1. P.45-53.

Tullgren A. 1910. Araneae // Wissenschaftliche Ergebnisse der Schwedischen Zoologischen Expedition nach dem Kilimandjaro, dem Meru und dem Umbegenden Massaisteppen Deutsch-Ostafrikas 1905-1906 unter Leitung von Prof. Dr Yngve Sjöstedt. Bd.20. No.6. S.85-172.

WSC 2016. World Spider Catalog. Version 17.5. Natural History Museum Bern. Available at http://wsc.nmbe.ch (accessed 15 August 2016).

Wunderlich J. 2011. Extant and fossil spiders (Araneae) // Beiträge zur Araneologie. Bn.6. S.1-640.

Zamani A., Marusik Yu.M., Berry J.W. 2016. A new species of Paratheuma (Araneae: Dictynidae) from Southwestern Asia and transfer of the genus // Zoology in the Middle East. Vol.62. No.2. P.177-183.

Responsible editor D.V. Logunov 